\title{
Improving the optimal composition of heat- insulating structural aerated concrete based on industrial waste
}

\author{
Said Shaumarov*, Sanjar Kandakhorov, and Umarali Abduraimov \\ Tashkent State Transport University, Tashkent, Uzbekistan
}

\begin{abstract}
This article presents the results of experimental research, which characterizes the parameters and properties of the porous structure of aerated concrete based on industrial waste. Structurally optimal parameters representing the physicalmechanical, thermal-technical properties of aerated concrete-based exterior wall structures have been identified. The test results were carried out in research laboratories using aerated block constructions with an optimal composition of high porosity and improved technological solutions of autoclaved aerated concrete.
\end{abstract}

\section{Introduction}

In today's world of advanced technology, the issue of recycling large amounts of waste that is spreading around the planet has become a pressing issue. Much work is being done around the world in this regard. For example, the concept of waste recycling and reducing their impact on the environment of the World Environmental Organization has a special place.

In the construction industry, as in all industries, the use of energy-saving materials, lowering the cost, the use of industrial waste products in construction is an effective raw material.

According to the results of laboratory tests, quartz sand used as industrial waste consists of the following indicators[1-2].

The use of heat-insulating effective building materials with an average density of 500$700 \mathrm{~kg} / \mathrm{m} 3$ and structural cellular concrete with an average density of $800-1200 \mathrm{~kg} / \mathrm{m} 3$ as energy-saving building materials increases its economic efficiency regard is important.

In developed countries, Germany, Sweden, the Russian Federation, the United States, Japan, Finland, and other countries are focusing on producing aerated concrete using industrial waste, increasing its heat, strength, moisture permeability [3]. This, in turn, has a positive effect on reducing the impact of industrial waste on the environment and increasing the economic efficiency of aerated concrete.

\footnotetext{
*Corresponding author: shoumarovss@gmail.com
} 
If we look at the world experience, using aerated concrete to increase the energy efficiency of the external barrier structures of energy-efficient buildings is important. At the same time, several manufacturing companies in developed countries, such as Wehrhahn, GRIVAS Ukraine, Masa, AltayStroyMash, East Mining Invest, Aerocon, increase the costeffectiveness of aerated concrete in research laboratories, using industrial waste, research is underway [9-20].

B.P. Danilov and A.A. Bagdanov [4] fully demonstrated the technological capabilities of aerated concrete barrier structures of different densities. At the same time, the thermal conductivity of the aerated concrete structure was $7-10 \%$, which allowed to eliminate the moisture formed on the inner surface of the structure, allowed to protect the working moisture from evaporation from the room by evaporation.

X. Xullmann, M. Schlaich, A. Lagoaz, P. Szymanski, P. Valczak, N.I. Levin, H. Weber's research results aim to improve the technology of aerated concrete and increase its efficiency [5-8].

In these studies, with the help of mineral and organic additives, plasticizers, research was conducted on various properties of aerated concrete, strength, thermal protection, optimization of porosity, reduction of moisture.

\section{Materials and Methods}

According to generally accepted standards, experimental studies were carried out using non-standard methods developed by scientific research experts, using laboratory wastes based on specified industrial wastes.

The study of the porous structure of aerated concrete blocks was performed using Thermo Scientific Pascal mercury porosimeter (Figure 1).

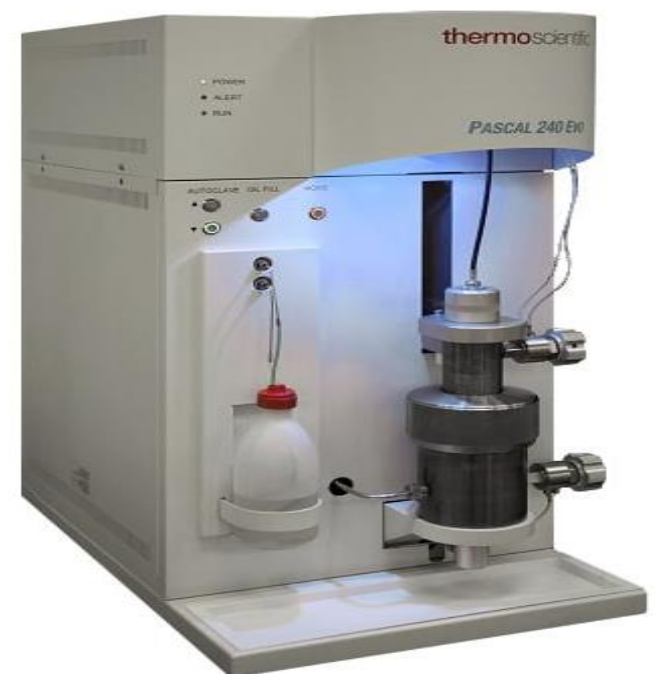

Fig.1. Thermo Scientific Pascal symbolic porosimeter

Experimental research and data processing were performed in the following sequence:

1. A vacuum for aerated concrete was created in the symbolic porosimeter "Thermo Scientific Pascal." The sample is filled into a vacuum flask, and mercury is added to it.

2. Mercury slowly enters the sample and fills its pores. The porosimeter then determines its porosity percentage based on the total size of the sample. 
3. Upon completing the experimental studies, the data are processed in the prescribed order using a special computer program, and the necessary diagrams are created.

Upon completion of the laboratory analysis, the computer will automatically describe the dimensions of the porosity of the samples, the penetration of mercury into them, and the pressure tolerance diagrams.

The strength of aerated concrete samples for strength following the normative requirements of GOST 10180-2012 was determined using a hydraulic press (Figure 2).

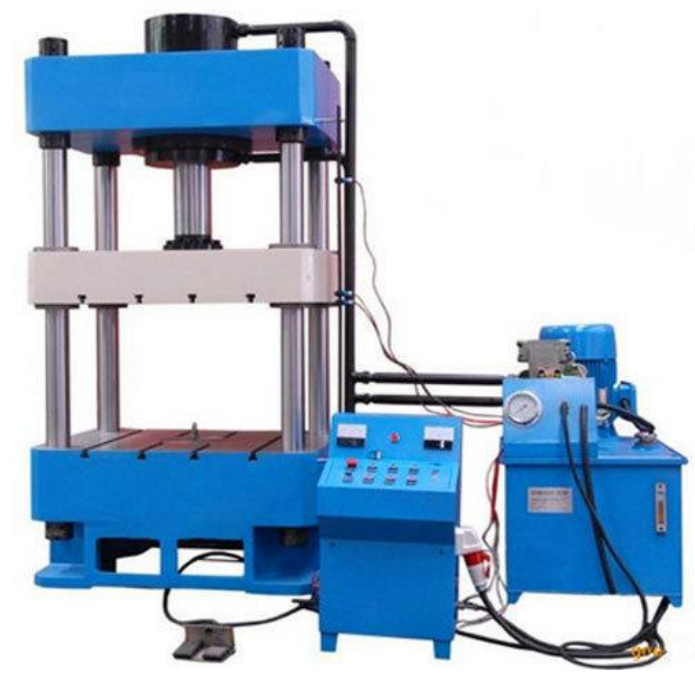

Fig. 2. Hydraulic press

Determining the optimal porosity content of the specified structural heat-insulating aerated concrete was performed using automated computer software [9-12].

Determination of the strength of aerated concrete samples using a hydraulic press was carried out in the following sequence:

1. Aerated concrete samples in the form of cubes of size $100 \times 100 \times 100 \mathrm{~mm}$ were mounted on the press, respectively.

2. The samples were gradually loaded with increasing force and lost their previous state.

3. The maximum breaking strength values were recorded for each sample.

4. The average refractive power of several samples was determined, and its grade was determined.

External wall constructions of energy-efficient civil buildings for different climatic conditions of the Republic of Uzbekistan with the required thermal conductivity values were implemented using computer programs "Base."

\section{Results and Discussion}

Study of physical, mechanical, and thermal properties of cellular concrete exterior wall structures determines criteria parameters of porosity of materials.

Aerated concrete blocks of D600 and D900 grades were selected for laboratory research. The prepared aerated concrete blocks consist of samples with dimensions of 100x100x100 mm (Fig. 3). 


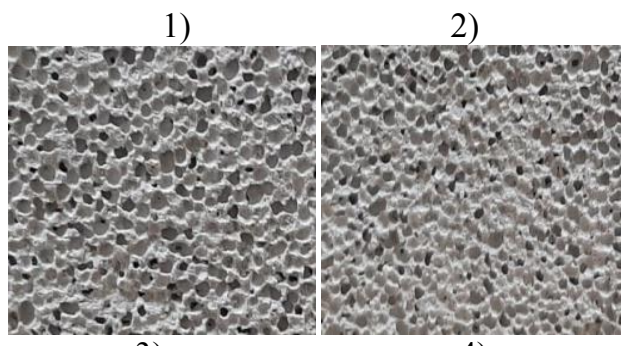

3)

4)

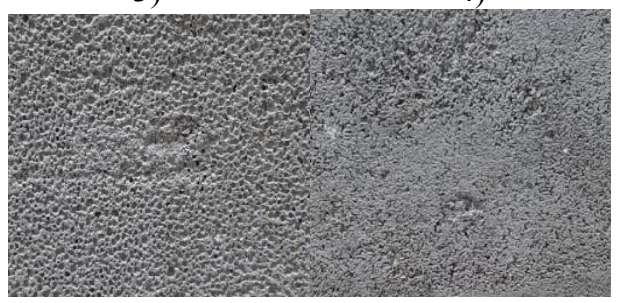

Fig.3. Exterior view of aerated concrete samples D600 $(1,2)$ and D900 $(3,4)$

Non-autoclaved aerated concrete samples were identified using a computer program "Determination of aerated concrete properties based on image analysis" using the standard method [9-11].

The calculation of the properties of aerated concrete samples using a porosimeter according to the results of experimental tests is given in Table 1.

Table 1.The results of determining the characteristics of samples in laboratories

\begin{tabular}{|c|c|c|c|}
\hline № & $\begin{array}{c}\text { Average density, } \\
\mathrm{kg} / \mathrm{m}^{3}\end{array}$ & $\begin{array}{c}\text { Density, } \\
\mathrm{MPa}\end{array}$ & Porosity,\% \\
\hline 1 & 645 & 1.64 & 63.2 \\
\hline 2 & 660 & 1.68 & 62.8 \\
\hline 3 & 652 & 1.65 & 62.9 \\
\hline 4 & 658 & 1.67 & 63.1 \\
\hline 5 & 858 & 5.84 & 58.3 \\
\hline 6 & 917 & 5.91 & 57.1 \\
\hline 7 & 862 & 5.87 & 58.1 \\
\hline 8 & 923 & 5.94 & 57.3 \\
\hline
\end{tabular}

The results of tests of the same samples by GOST 10180-2012 are given in Table 2. 
Table 2. Results of determining the characteristics of samples in production organizations

\begin{tabular}{|c|c|c|c|}
\hline № & $\begin{array}{c}\text { Average } \\
\text { density. } \\
\mathrm{kg} / \mathrm{m}^{3}\end{array}$ & $\begin{array}{c}\text { Density. } \\
\mathrm{MPa}\end{array}$ & $\begin{array}{c}\text { Porosi } \\
\text { ty.\% }\end{array}$ \\
\hline 1 & 646 & 1.52 & 61.8 \\
\hline 2 & 667 & 1.58 & 60.2 \\
\hline 3 & 656 & 1.53 & 61.4 \\
\hline 4 & 662 & 1.56 & 60.5 \\
\hline 5 & 861 & 4.86 & 56.2 \\
\hline 6 & 889 & 4.92 & 54.4 \\
\hline 7 & 868 & 4.88 & 55.2 \\
\hline 8 & 892 & 4.96 & 53.8 \\
\hline
\end{tabular}

A comparison of the average density, strength, and porosity of non-autoclaved aerated concrete samples determined by the proposed standard methods showed that the average density difference was (1-4)\%; strength - $(6.5-10.4) \%$; in terms of porosity - $(1.3-4 \%)$.

However, the results obtained from the experiments on strength showed that the actual strength of D600 non-autoclaved aerated concrete is (10-12) \% lower than indicated in the passport, D900 grades (6-8)\% lower.

Studies have shown that it is possible to improve the thermal-technical and structural properties of aerated concrete, taking into account several factors, and to obtain a lot of real practical results from the analysis of the literature, optimize the porosity of aerated concrete and its application in thermal insulation buildings for all levels of Uzbekistan, technological methods have been developed that can be successfully applied in the field.

The technology developed for the production of autoclaved aerated concrete was tested in the production organizations. For this purpose, the compositions D600 and D900 were mixed following the developed technology. The samples were determined according to the porosity properties according to the standard method developed (Figure 4) [21-28].

a)

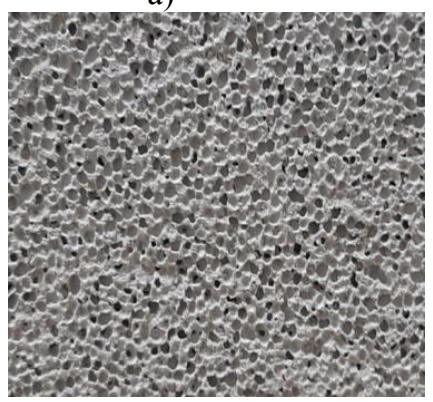

b)

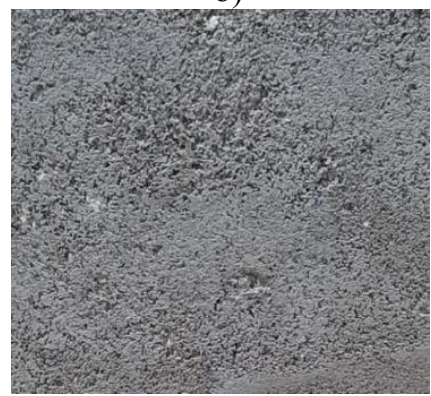

Fig.4. Photographs of surfaces of non-autoclaved aerated concrete samples D600 (a) and D900 (b)

Samples from each batch were investigated using the developed standard method; the results obtained are presented in table 3 . 
Table 3. Results of determining the characteristics of aerated concrete samples by the standard method

\begin{tabular}{|c|c|c|c|}
\hline № & $\begin{array}{c}\text { Average } \\
\text { density. } \mathrm{kg} / \mathrm{m}^{3}\end{array}$ & $\begin{array}{c}\text { Density. } \\
\mathrm{MPa}\end{array}$ & $\begin{array}{c}\text { Porosity, } \\
\%\end{array}$ \\
\hline 1 & 615 & 1.62 & 63.2 \\
\hline 2 & 632 & 1.68 & 62.5 \\
\hline 3 & 609 & 1.60 & 64.3 \\
\hline 4 & 624 & 1.63 & 62.9 \\
\hline 5 & 898 & 5.84 & 58.7 \\
\hline 6 & 920 & 5.96 & 57.9 \\
\hline 7 & 906 & 5.91 & 58.3 \\
\hline 8 & 917 & 5.93 & 58.1 \\
\hline
\end{tabular}

The porosity structure of the samples was checked using a porosimeter. According to the results of the study, the samples with the best characteristics were identified. The results of this experimental study are shown in Figure 5.

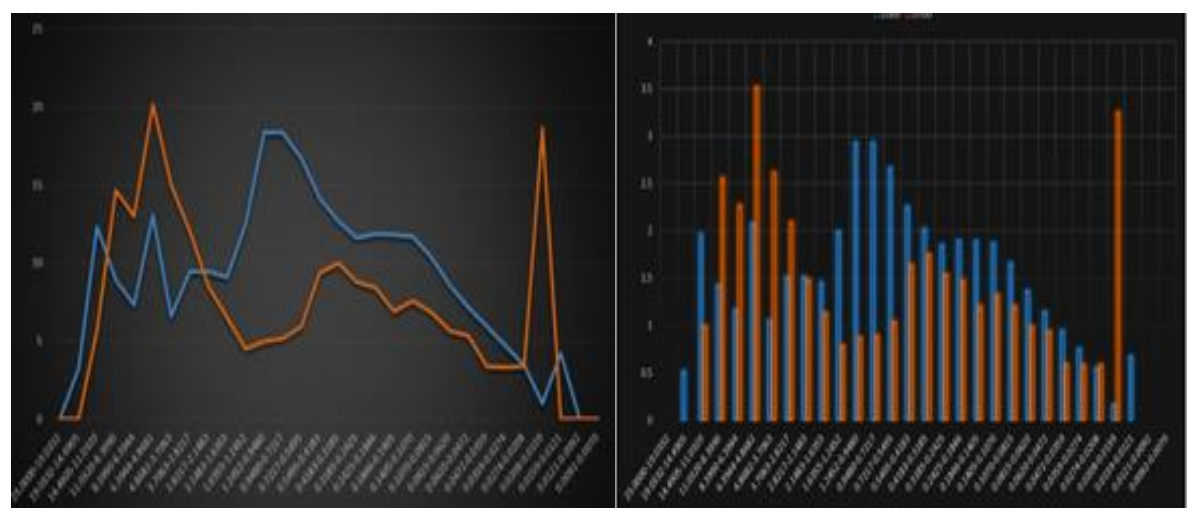

Fig. 5. Density porosity diagram of aerated concrete cells D 600. D900

As can be seen from the graph, we can determine the parameters and porosity percentages of energy loss from the parts of gas blocks and their resistance to strong pressure. In this case, the results of strength, porosity, moisture permeability, and fire resistance of gas blocks were compared. According to the comparison results, the advantage was $10.5 \%$ in the samples of D600 grade and $8.6 \%$ in the aerated concrete blocks of D900 grade.

Analyzing the obtained results, the ease of determining aerated concrete properties using the established standard methods, its average density of $1-3 \%$; strength of $7.5-11.4 \%$; porosity of $2-3.8 \%$ difference. 
Table 4.Technical characteristics of autoclaved gas units obtained based on different technologies in different conditions

\begin{tabular}{|c|c|c|c|c|}
\hline \multirow{2}{*}{$\begin{array}{c}\text { Composition, production conditions, } \\
\text { technology }\end{array}$} & \multicolumn{4}{|c|}{ Aerated concrete grade } \\
\cline { 2 - 5 } & \multicolumn{4}{|c|}{ Characteristics of aerated concrete } \\
\cline { 2 - 5 } & $\begin{array}{c}\text { Density, } \\
\mathrm{MPa}\end{array}$ & $\begin{array}{c}\text { Porosity, } \\
\%\end{array}$ & $\begin{array}{c}\text { Density, } \\
\mathrm{MPa}\end{array}$ & $\begin{array}{c}\text { Porosity } \\
\%\end{array}$ \\
\hline $\begin{array}{c}\text { Features of gas blocks in the } \\
\text { production organization }\end{array}$ & 1.51 & 61.1 & 4.9 & 56.0 \\
\hline Features of the proposed gas block & 1.68 & 63.5 & 5.86 & 59.1 \\
\hline
\end{tabular}

Analysis of the results of scientific research in autoclaved aerated concrete structures in research laboratories and production organizations showed that the material's porosity has a significant impact on its thermal and technical properties, strength.

\section{Conclusions}

1. According to the results of laboratory research conducted in industrial organizations and the developed method, the risk of dangerous cracks of porous autoclaved non-autoclaved gas blocks improved by $1-3 \%$, porosity by $2.1-4.3 \%$.

2. It is possible to increase the strength of the proposed gas blocks by $20-21 \%$, sound insulation by $2-5 \%$.

3. The results of the conducted experimental research laboratories showed that when the gas block was formed using waste sand, its cost was reduced by $2-3 \%$.

4. In the process of production of aerated concrete blocks, the inclusion of the above and other types of industrial waste in the concrete composition, first of all, allows to save waste processing (disposal), binder (cement), increase the operational properties of the structure.

\section{References}

1. Khasanov. B.. Vatin. N.. Ismailova. Z. Mirzaev. T. Physical modification of concrete mix and concrete, IOP Conference Series: Materials Science and Engineering. 883 (1). 012205 (2020).

2. Khasanov. B.. Irmuhamedova. L.. Firlina. G.. Mirzaev. T. Theoretical foundations of the structure formation of cement stone and concrete IOP Conference Series, Materials Science and Engineering. 869 (3). 032032. (2020),

3. Adilkhodjaev. A.. Makhamataliev. I.. Tsoy. V.. Shaumarov. S.. Ruzmetov. F. Features of Forming the structure of cement concrete on second crushed stone from concrete scrap, International Journal of Advanced Science and Technology. 29 (5). pp. 19011906. (2020).

4. Danilov B.P.. Bogdanov A.A. Enclosing structures made of aerated concrete of variable density. M .: Stroyizdat. p 102. (1993).

5. Weber H.. Hullmann H. Porobeton Handbuch. Planen und Bauenmit System. Gtersloh: Bertelsmann SpringenBauverlag. p 278. (2002)

6. Schlaich M. Infra lightweight concrete - potencial for fair-faced concrete applications. M. Schlaich. BFT INTERNATIONAL. 2. pp. 118-120. (2007).

7. Lagoaz A.. Szymanski P.. Walczak P. Influence on the fly ash properties on properties of autoclaved aerated concrete. International Conference on Autoclaved Aerated Concrete.14-17 September. 2011. Poland. (2011). 
8. Pinsker V.A. Some questions of the physics of aerated concrete, Sat. works "Dwelling houses from aerated concrete". - L .: Goststroyizdat. Leningrad branch. pp. 123-143. (1993).

9. Anvar. A.. Shaumarov. S.. Elena. S.. Ulugbek. S. New method for diagnostic of heat engineering and mechanical properties of cellular concrete, International Journal of Engineering and Advanced Technology. 9 (1). pp. 6885-6887. (2019)

10. Ishanovich. A.A.. Vladimirovna. S.E.. Shaumarov. S.. Zabihullaevich. S.U.. Ishratovich. K.S. Some aspects of the photo-optical method of estimation composition of light concrete, International Journal of Engineering and Advanced Technology. 8 (5). pp. 1924-1927. (2019)

11. Adilkhodjaev. A.. Shaumarov. S.. Kadir. U. New structure assessment method cell concrete, International Journal of Advanced Science and Technology. 29 (5). pp. 1889-1893. (2020).

12. Adilkhodjaev. A.. Tsoy. V.. Khodzhaev. S.. Shaumarov. S.. Umarov. K. Research of the influence of silicon-organic hydrophobizer on the basic properties of cement stoneand mortar, International Journal of Advanced Science and Technology. 29 (5). pp. 1918-1921. (2020).

13. Khadjimukhametova. M. A.. Merganov. A. M. Method for calculating the injection effect to create air circulation inside containers. International Journal of Innovative Technology and Exploring Engineering. 9 (1). pp.3222-3224. doi:10.35940/ijitee.A9160.119119

14. Ilesaliev. D.. Avaz. M. Research package efficiency general cargo. International Journal of Engineering and Advanced Technology. 9 (1). pp.6880-6884. doi:10.35940/ijeat.A2992.109119.

15. U. Shermuxamedov. S.Salixanov. S.Shaumarov. F.Zokirov. Method of selecting optimal parameters of seismic-proof bearing parts of bridges and overpasses on highspeed railway lines. European Journal of Molecular and Clinical Medicine. ISSN 2515-8260. (7). pp. 1076-1084. (2020).

16. U.Z. Shermukhamedov. T.R. Rashidov. Features of the theory of a two-mass system with a rigidly connected end of the bridge. in consideration of seismic influence on high-speed railways. European Journal of Molecular and Clinical Medicine. ISSN 2515-8260.(7). pp. 1160-1166. (2020).

17. Huber Peter. Realized projects of Isolation Systems for Railway Bridges in Spain. Hungary and Greece. in the PROCEEDINGS OF WORKSHOP Bridges seismic isolation and large-scale modeling Saint-Petersburg pp. 37 - 50. (2010)

18. Dolgaya A.A. Kuznetsova I.O. Uzdin A.M. Frese M.V. Shulman S.A.. Seismic resistance of railway bridges. Science and transport. 4. pp 43-47. (2012)

19. Zhgutova T.V. Kuznetsova I.O. Uzdin A.M. Shulman S.A, Seismic isolation of railway bridges in Sochi. Proceedings of the meeting of the working group of the international society on seismic protection systems (ASSISi). pp 119-132. (2011)

20. Zhgutova T.V, Assessment of the track performance on bridges with seismic isolation and requirements for seismic isolation. taking into account the track performance. Bulletin of the Petersburg State University of Railways. 3. pp. 199-204 (2012).

21. Uzdin A.M.. Elizarov S.V. Belash T.A, Earthquake resistant structures of transport buildings and structures. Tutorial. FGOU "Educational and methodological center for education in railway transport". p 500 (2012)

22. Uzdin A.M. Kuznetsova I.O, Seismic resistance of bridges. Saarbrucken (Germany). Palmarium. p. 450 (2014)

23. Uzdin A.M, On the account of energy dissipation in assessing the seismic resistance of transport structures. Seismic resistance of transport and network structures. Moscow. Nauka. pp. 35-44 (1986) 
24. Adilkhodjaev A., Hasanov B., Shaumarov S., Kondrashchenko V. Aerated concrete with predetermined pore parameters for the exterior walls of energy efficient buildings, IOP Conference Series: Materials Science and Engineering, 1030(1), 012006, (2021)

25. Khasanov B., Vatin N., Mirzaev T., Suyunov A., Radjabov M. Analysis of the mode of squeezing out excess water for mixing concrete mixture in the process of peristaltic compaction, IOP Conference Series: Materials Science and Engineering, 1030(1), 012021, (2021)

26. Khasanov B., Vatin N., Mirzaev T., Suyunov A., Radjabov M. Physicochemical fundamentals of modifying concrete mix and concrete, IOP Conference Series: Materials Science and Engineering, 2021, 1030(1), 012022

27. Khasanov B., Vatin N., Ismailova Z., Mirzaev T. Physical modification of concrete mix and concrete, IOP Conference Series: Materials Science and Engineering, 883(1), 012205, (2020)

28. Khasanov B., Irmuhamedova L., Firlina G., Mirzaev T. Theoretical foundations of the structure formation of cement stone and concrete, IOP Conference Series: Materials Science and Engineering, 869(3), 032032, (2020) 